\title{
Serratia strains isolated from the rhizosphere of raulí (Nothofagus alpina) in volcanic soils harbour PGPR mechanisms and promote raulí plantlet growth
}

\author{
Oscar A. Martínez ${ }^{1,2, *}$, Carolina Encina ${ }^{1}$, Camilo Tomckowiack ${ }^{1}$, Fernando Droppelmann ${ }^{3}$, \\ Ronald Jara $^{1}$ Constanza Maldonado ${ }^{1}$, Ociel Muñoz ${ }^{4}$, Paula García-Fraile ${ }^{5}$, Raúl Rivas ${ }^{6,7,8}$
}

${ }^{1}$ Instituto de Bioquímica y Microbiología, Facultad de Ciencias, Universidad Austral de Chile, Valdivia, Chile. ${ }^{2}$ Centro de Investigación en Suelos Volcánicos, Universidad Austral de Chile, Valdivia, Chile. ${ }^{3}$ Instituto de Bosques y Sociedad, Facultad de Ciencias Forestales y Recursos Naturales, Universidad Austral de Chile, Valdivia, Chile. ${ }^{4}$ Instituto de Ciencia y Tecnología de los Alimentos, Facultad de Ciencias Agrarias, Universidad Austral de Chile, Valdivia, Chile. ${ }^{5}$ Microbiology Institute. Academy of Sciences of the Czech Republic. Prague, Czech Republic. ${ }^{6}$ Departamento de Microbiología y Genética. Universidad de Salamanca. Spain. ${ }^{7}$ Instituto Hispano-Luso de Investigaciones Agrarias (CIALE).Salamanca Spain. ${ }^{8}$ Unidad Asociada Universidad de Salamanca-CSIC (IRNASA), Salamanca, Spain. *Corresponding author: oscar.martinez@uach.cl

\begin{abstract}
Rauli is one of the most emblematic tree species of the Chilean temperate forests. Due to the high quality wood, this tree has been used for furniture and handicrafts manufacturing, which has positioned raulí as one of the most important commercial timber species in Chile. Currently, the international market demands sustainable production system for forest production, more specifically in plantlets production. In this regard, plant growthpromoting rhizobacteria (PGPR) inoculants may enhance the growth and survival of plantlets in nurseries, which means an increase in the effectiveness of replanting operations. Therefore, the aim of the present study was to isolate, characterize and screen rhizosphere-associated bacteria with PGPR potential, isolated from raulí that growth in volcanic soils in southern Chile. A total of 1,261 bacterial strains were isolated from different volcanic soils. Out of 1,261 isolates, 100 were selected based on their high levels of indole acetic acid (IAA) production. These isolates were then subjected to screening for 1-aminocyclopropane-1-carboxylic acid deaminase activity, and their ability to fix nitrogen was determined. From the 100 selected isolates, 7 were chosen for producing the highest amount of IAA to continue with genetic characterization based on their 16S rRNA gene sequences. These 7 isolates were characterized as members of the Serratia genus and were used to develop multi-strain inoculant mixtures. Later, a nursery study followed to determine the effect of inoculation with the Serratia strains on the growth of RA88 raulí clone plantlets. The nursery experiment demonstrated that Serratia strains have the potential to increase the root collar diameter, height, relative chlorophyll content, biomass and nitrogen content of raulí plantlets. The study concluded, that Serratia strains have the potential to be used as biofertilizers to increase plant growth in nursery conditions.
\end{abstract}

Keywords: Rhizobacteria, volcanic soil, plant nursery, indole acetic acid, bio-inoculant, forestry, root development. 


\section{Introduction}

Nothofagus alpina Poepp. et Endl. Oerst. (= N. nervosa) commonly known as raulí, is an endemic tree species of subantarctic deciduous-temperate forests (Donoso et al., 2006; Beltran et al., 2017). Raulí is a species that can reach up to $3 \mathrm{~m}$ in diameter and 35-40 m in height. In the Andes Mountains the natural distribution of raulí is between $35^{\circ} 13^{\prime} \mathrm{S}$ and $37^{\circ}$ S. Raulí forest ecosystems are naturally located on soils formed from the deposition of volcanic ash on volcanic rock substratum (Donoso et al., 2006). In southern Chile, volcanic soils (andisols) are the predominant soils that support the bulk of agriculture and forestry production. Andisols are characterized by low $\mathrm{pH}(4.8-5.8)$ and a high content of organic matter (Valle and Carrasco, 2018). Among native species, raulí appears to have the greatest potential for commercial use. Due to its rapid growth and wood properties, there is growing demand for this species for use in afforestation, reforestation and enrichment. Furthermore, the high quality of rauli wood is ideal for building and making furniture and handicrafts. Overall, raulí has the potential to become one of the most important commercial forestry species in Chile (Beltran et al., 2017).

Plantations of new raulí forests are becoming more prevalent. Specifically, raulí plantlets are grown in plant nurseries until they reach an appropriated size and root development to be successfully transplanted to their final location in andisols. The productivity of plant nurseries depends on the time that the seedlings require to be ready to be transplanted, and therefore the use of chemical products to promote the first tree development stages is quite common. Currently, there is a need to develop nursery production systems that are friendly to the environment (cleaner technologies). One alternative to the application of chemical fertilizers and pesticides includes the use of plant growth-promoting rhizobacteria (PGPR). Inoculation of agricultural crops with PGPR has been done for many years with encouraging results. Despite of this, research on the application of PGPR to tree species is very limited except for possible use in diseases control in forest nurseries (Chanway, 1997; Lucy et al., 2004; Karličić et al., 2016). Moreover, most of the studies on tree growth promotion focus on gymnosperm species (Lucy et al., 2004).

Currently, there is an increasing interest in the use of beneficial microorganisms as inoculants for nursery tree seedlings or plantlets (Chanway, 1997; Karličić et al., 2016) due to the positive results obtained in agriculture and horticulture, and due to the low cost, environmental friendliness, and easy application of microbial inoculations (Chanway, 1997; Kavino et al., 2010). Recent studies have shown that PGPR inoculants can exert beneficial effects on tree plantlets or seedlings increasing their survival in nurseries, increasing their stress tolerance, and improving the effectiveness of forest replanting operations (Kavino et al., 2010; Karličić et al., 2016). However, there is little information on the effect of PGPR inoculation on the growth and nutrient accumulation of native forest plantlets. There are several possible mechanisms through which PGPR can affect forest plant growth and development (Lucy et al., 2004; Karličić et al., 2016; Zavattieri et al., 2016), for example, production of indole acetic acid and atmospheric nitrogen fixation have stimulated the growth of Ilex paraguariensis seedlings (Bergottini et al., 2015), Cocos nucifera seedlings (George et al., 2013) and Eucalyptus nitens seedlings (Angulo et al., 2014). These studies clearly suggested the potential of PGPR as a pre-plantation nursery treatment.

PGPR strains are broadly distributed among many genera including Azoarcus, Azospirillum, Bacillus, 
Burkholderia, Enterobacter, Gluconacetobacter, Pseudomonas and Serratia (Martinez-Viveros et al., 2010). Members of the genus Serratia exist in a wide range of habitats and have diverse ecological functions such as pathogenic, mutualistic, and antagonistic associations (Grimont and Grimont, 2006; Petersen and Tisa, 2013). The ubiquity of Serratia is largely attributed to the variety of compounds that they release into the environment (Petersen and Tisa, 2013). Serratia are Gram-negative, facultative anaerobic, rod-shaped bacteria of the Enterobacteriaceae family (Petersen and Tisa, 2013). Different species belonging to the Serratia genus are well-known PGPR, and strains have been isolated from the rhizosphere of crops. Plant-associated Serratia improve the health and development of their host plant by several mechanisms such as by producing indole acetic acid (Koo and Cho, 2009; Dastager et al., 2011; George et al., 2013), by fixing nitrogen (George et al., 2013), by 1-aminocyclopropane-1-carboxilate deaminase activity (George et al., 2013), by solubilizing phosphate (Dastager et al., 2011; George et al., 2013), by producing siderophores (Koo and Cho, 2009; Dastager et al., 2011) and by inducing systemic resistance of the host plant (Singh and Jha, 2016). A positive role for Serratia species in growth promotion have been demonstrated on several plant species, including black pepper (Dastager et al., 2011), corn (Koo and Cho, 2009), wheat (Singh and Jha, 2016) and coconut palms (George et al., 2013).

In view of the above considerations, Serratia species have great potential as plant inoculants. However, to the best of our knowledge, there are no studies to date that focus on indigenous Serratia strains as inoculants for improving growth of native tree species with forestry importance in volcanic soils. In this context, the objective of the present study was the isolation, characterization, and selection of bacteria from rauli rhizosphere for their biotechnological potential as
PGPR. Subsequently, we selected the Serratia strains with the best plant growth promoting (PGP) potential to evaluate the effects of direct inoculation on the growth of raulí plantlets in nursery conditions.

\section{Materials and Methods}

\subsection{Soil sampling and analysis of chemical properties} of the rhizosphere of volcanic soils

Rhizospheric soil samples were collected from raulí grown in different volcanic soils from Los Ríos Region (Table 1). Three independent samples were collected from each soil series. The chemical properties of the rhizospheric soil samples, such as $\mathrm{pH}$, total nitrogen $(\mathrm{Nt})$, phosphorus availability (Olsen $\mathrm{P}$ ), soil organic matter (SOM) and aluminium (Al) saturation, were analysed using the methods revised by Sadzawka et al. (2006) and officially recommended for Chilean soils. Soil $\mathrm{pH}$ was measured in 1:2.5 soil/deionized water. $\mathrm{Ni}$ was extracted with $2 \mathrm{M} \mathrm{KCl}$ and $\mathrm{NO}_{3}{ }^{-}-\mathrm{N}$ was determined with Devarda alloy distillation methods. $P$ was extracted by the Olsen bicarbonate method and analysed by the Murphy and Riley method. SOM was estimated by wet digestion with a modified WalkleyBlack procedure. Al saturation was calculated as a percentage of the cation exchange capacity.

\subsection{Isolation, screening of plant growth promoting traits, and selection of indole acetic acid producing rhizobacteria}

\subsubsection{Isolation of rhizobacteria}

The rhizobacterial strains were isolated via serial dilution in three common types of agar media: nutritive agar (NA), Jensen agar (JA) and soil extract agar (SEA). Petri plates were incubated 4-7 days at $22 \pm 2$ ${ }^{\circ} \mathrm{C}$ in the dark. After the incubation period, bacterial 
colonies developed were chosen based on their colony morphology and pigmentation; approximately 50 colonies were isolated from each type of agar media for each of the three samples taken from each soil series. Bacterial cultures were stored in nutritive broth with $30 \%$ glycerol at $-80{ }^{\circ} \mathrm{C}$ until further use. Subsequently, in vitro screening for plant growth-promoting traits such as the production of indole acetic acid (IAA), 1-aminocyclopropane-1-carboxylic acid deaminase (n) activity, and biological nitrogen fixation (BNF) were carried out (George et al., 2013; Etesami et al., 2015).

Table 1. Sample site characteristics

\begin{tabular}{cccccc}
$\begin{array}{c}\text { Volcanic } \\
\text { soil series }\end{array}$ & Order & $\begin{array}{c}\text { N. alpina } \\
\text { management }\end{array}$ & Coordinates & m.a.s.l. & Soil age $^{a^{a}}$ \\
\hline Pelchuquín & Andisol & Plantation & $\begin{array}{l}\text { Lat: }-39.609717^{\circ} \mathrm{S} \\
\text { Long: }-73.073683^{\circ}\end{array}$ & 27 & +++ \\
San José & Andisol & Plantation & $\begin{array}{l}\text { Lat: }-39.549141^{\circ} \mathrm{S} \\
\text { Long: }-73.071677^{\circ}\end{array}$ & 23 & +++ \\
Malihue & Andisol & Plantation & $\begin{array}{l}\text { Lat: }-39.544206^{\circ} \mathrm{S} \\
\text { Long: }-72.324136^{\circ}\end{array}$ & 287 & ++ \\
Liquiñe & Andisol & Native forest & $\begin{array}{l}\text { Lat: }-39.837415^{\circ} \mathrm{S} \\
\text { Long: }-71.961761^{\circ}\end{array}$ & 455 & + \\
& Lltisol & Plantation & $\begin{array}{l}\text { Lat: }-39.7510^{\circ} \mathrm{S} \\
\text { Long: }-73.1524^{\circ}\end{array}$ & 118 & +++ \\
\hline
\end{tabular}

a + young, ++ intermediate and +++ old. M. a. s. 1.: Meters above sea level.

\subsubsection{Determination of indole acetic acid production}

The first method used to screen the isolated rhizobacterial production of indole acetic acid was colorimetric quantification of indolic compounds. The ability of the isolates to produce indole compounds was detected in nutritive broth supplemented with L-tryptophan (5 mM) (Martínez et al., 2011). Qualitative detection and quantitative estimation of indole compounds were accomplished using the standard methods described by Patten and Glick (2002). Quantitative estimation was carried out in $15 \mathrm{~mL}$ tubes. After incubation $\left(48 \mathrm{~h}\right.$ at $30{ }^{\circ} \mathrm{C}$ with shaking), bacterial cells were removed from the culture medium by centrifugation at $10,000 \times \mathrm{g}$ for 10 min. $1 \mathrm{~mL}$ of supernatant was mixed with $2 \mathrm{~mL}$ of Salkowski's reagent $(150 \mathrm{~mL}$ of concentrated
$\mathrm{H}_{2} \mathrm{SO}_{4}, 250 \mathrm{~mL}$ of distilled $\mathrm{H}_{2} \mathrm{O}, 7.5 \mathrm{ml}$ of $0.5 \mathrm{M}$ $\left.\mathrm{FeCl}_{3} \cdot 6 \mathrm{H}_{2} \mathrm{O}\right)$ and incubated at room temperature for 30 min (Patten and Glick, 2002). Appearance of a red colour indicated indole compound production. The colour intensity was determined by measuring the optical density at $530 \mathrm{~nm}$ using a spectrophotometer (Metertek SP-830). The concentration of indole compounds was determined by comparison with a standard curve prepared with known concentrations of IAA (Sigma-Aldrich). The amount of indole compounds produced was expressed as $\mu \mathrm{g} \mathrm{mL}^{-1}$. Three independent replicates of each isolate were analysed. All isolates were ranked based on their in vitro indole compound production.

The second method used to confirm and quantify IAA production was high performance liquid chromatography (HPLC) with fluorescence detection 
(Dastager et al., 2011; Angulo et al., 2014). In order to evaluate specific IAA production, this methodology was applied to the 100 highest indole compound producing strains. A Shimadzu (Japan) HPLC instrument equipped with a variable-wavelength UV spectrometer was used. After cultivating the strains, the supernatant was filtered through 0.22 micron filters. Chromatographic separation was then performed by injecting a $20 \mu \mathrm{L}$ aliquot into a C18 reverse phase column (Supelco, Bellefonte, PA, USA). The fluorescence detector was set with an excitation wavelength (Ex) of $280 \mathrm{~nm}$ and an emission wavelength (Em) of $360 \mathrm{~nm}$. A 60:40 mixture of methanol and acetic acid was used as the mobile phase. This was supplied at a flow rate of $1 \mathrm{~mL} \mathrm{~min}-1$ and at a temperature of $23{ }^{\circ} \mathrm{C}$. Final$1 y$, the concentration of IAA at each sample was quantified by obtaining the area of the peaks and by interpolation with an IAA calibration curve.

\subsubsection{Determination of ACC deaminase activity}

The ability of the strains to hydrolyse 1-aminocyclopropane-1-carboxylic acid (ACC) was assayed according to Penrose and Glick (2003) and Viscardi et al. (2016). Two methodologies were applied. First, bacterial isolates were screened for ACC deaminase activity by plating on M9 minimal medium containing ACC as the sole nitrogen source. Second, ACC deaminase activity was determined by measuring the concentration of $\alpha$-ketobutyrate. Briefly, bacterial cells were grown in M9 minimal medium broth containing ACC as the sole nitrogen source. The amount of $\alpha$-ketobutyrate in the supernatant was determined by HPLC-PAD (Waters Alliance 2690 HPLC system, Waters 2996 PDA) after centrifugation at $3000 \mathrm{rpm}$ for $10 \mathrm{~min}$. The analyses were carried out using a C 8 column (Phenomenex, Luna C8, $250 \times 4.6 \mathrm{~mm}, 5 \mu \mathrm{m}, 100 \mathrm{~A})$ at $30{ }^{\circ} \mathrm{C}$, using a phosphate buffer mobile phase (50 mM, pH 3.0). The flow rate was $1.0 \mathrm{~mL} \mathrm{~min}^{-1}$. Quantification was carried out at $220 \mathrm{~nm}$ by external calibration using pure $\alpha$-ketobutyrate (Sigma).

\subsubsection{Potential capacity to fix biological nitrogen}

To evaluate the potential capacity to fix nitrogen, two indirect methods were utilized. Biological nitrogen fixation (BNF) was tested on nitrogen-free medium (George et al., 2013). Bacterial isolates were further screened by plating on Jensen medium without a nitrogen source and incubating at $28 \pm 2{ }^{\circ} \mathrm{C}$ for $48 \mathrm{~h}$. Growth on the medium reflected the potential ability of bacteria to fix atmospheric nitrogen. Furthermore, the BNF ability of the isolates was assessed by nif $\mathrm{H}$ molecular detection using polymerase chain reaction (PCR) according to Wartiainen et al. (2008). Briefly, PolF/PolR and PolFI/AQER primers designed for soil diazotrophs were used in PCR to molecularly detect the nif $\mathrm{H}$ gen. In the first $\mathrm{PCR}$ reaction, a 370 base pair fragment of the nif $\mathrm{H}$ gene was amplified using the PCR primers PolF and PolR. In the second PCR, the PCR primers PolFI/AQER were used. The PCR amplifications were carried out with reagents supplied with GoTaq ${ }^{\circledR}$ Flexi DNA Polymerase (Promega Co.) as follows: a hot-start was performed at $95{ }^{\circ} \mathrm{C}$ for 10 min, followed by 30 cycles of $1 \mathrm{~min}$ at $94{ }^{\circ} \mathrm{C}, 1 \mathrm{~min}$ at $55^{\circ} \mathrm{C}$, and $1 \mathrm{~min}$ at $72{ }^{\circ} \mathrm{C}$ followed by a final extension of $10 \mathrm{~min}$ at $72{ }^{\circ} \mathrm{C}$. PCR products were analysed on a $1 \%$ agarose gel (LE Agarose, Cleaver Scientific Ltd., USA) stained with GelRed ${ }^{\mathrm{TM}}$ (Biotium Inc., USA) and visualized under LED light.

\subsection{Genetic identification and phenotypic characterization of selected IAA-producing rhizobacteria}

Isolates were ranked based on in vitro IAA production, and 7 superior rank isolates were selected and 
characterized using common molecular biology methods. To study the molecular diversity of the IAA-producing rhizobacteria, all selected isolates were subjected to genotyping, identification, and phenotypic characterization.

\subsubsection{Genotyping by ERIC-PCR analysis}

In order to avoid further analysis of strains with the same genotype, the isolates were genotyped using the enterobacterial repetitive intergenic consensus PCR (ERIC-PCR) technique following the Houf et al. (2002) protocol. Patterns with at least one different band were considered as different genotypes. The cluster analysis of band patterns was carried out with the Phoretix 1D analysis software (TotalLab Ltd.).

2.3.2. Identification by $16 \mathrm{~S}$ rRNA gene amplification and sequencing

Selected IAA-producing strains were genetically identified according to $16 \mathrm{~S}$ rRNA gene sequencing (Coenye et al., 1999). Briefly, genomic DNA was extracted from bacterial cultures grown overnight at $30^{\circ} \mathrm{C}$ in nutritive broth. Amplification of the 16S rDNA gene was performed by PCR using the internal primers described by Coenye et al. (1999). The 16S rDNA fragments were sequenced by Macrogen (Seoul, Korea). Isolates were identified using 16S rRNA sequence data from the EzTaxon server (http://www.ezbiocloud.net/eztaxon). Nucleotide sequences obtained in this study have been submitted to GenBank under the following accession numbers (MF716551 to MF716557). Phylogenetic analyses with the $16 \mathrm{~S}$ rDNA sequences of the seven bacterial isolates were conducted using the software MEGA 6 (http://www.megasoftware.net/).
2.3.3. Phenotypic characterization of selected IAAproducing rhizobacteria

Morphophysiological and biochemical characteristics of selected IAA-producing rhizobacteria were examined according to MacFaddin (2000). Specifically, the following traits were determined: Gram staining, development in Salmonella-Shigella culture media (Merck, Darmstadt, Germany), development in MacConkey media (Becton, Dickinson and Company, Le Pont de Claix, France), development at different temperatures $22{ }^{\circ} \mathrm{C}, 37^{\circ} \mathrm{C}$ and $42{ }^{\circ} \mathrm{C}$, haemolysis on sheep blood agar plates, and fermentation of lactose, glucose, arabinose and sorbitol (1\% each). Catalase activity was evaluated by adding a $3 \% \mathrm{H}_{2} \mathrm{O}_{2}$ solution and observing the reaction within $5 \mathrm{~s}$. Oxidase activity was determined with Bactident Oxidase strips (Merck).

\subsection{Nursery experiment with IAA-producing bacteria}

This experiment was carried out in the shadehouse of the nursery at Centro Experimental Forestal (CEFOR), Universidad Austral of Chile, between autumn and spring 2015. A nursery assay was conducted to determine the effect of mixtures of potential PGPR on the growth of rauli plantlets (RA88 clone). Plantlets were two months old and obtained through vegetative propagation. Raulí plantlets were grown in nursery substrate: $50 \%$ peat, $50 \%$ perlite, $3 \mathrm{~g} \mathrm{~L}^{-1}$ Basacote ${ }^{\circledR}$ Plus (COMPO, Germany) and $160 \mathrm{gm}^{-3}$ Pomarsol ${ }^{\circledR}$ Forte $80 \%$ WG (Bayer CropScience).

Selected rhizobacterial strains were -mixtures with different combinations of plant growth promoting traits. Four different treatments were used: control non-inoculated, mix 1, mix 2 and mix 3. Each bacterial mixture contained a different number of strains harbouring different traits related to the promotion of plant growth. 
Plantlets were inoculated with a bacterial suspension $\left(10^{8}\right.$ CFU mL $\left.{ }^{-1}, 50 \mathrm{~mL}_{\text {plant }}{ }^{-1}\right) 1,3,5$ and 7 months after the trial started. Briefly, each strain was grown separately in nutrient broth (Merck) at $23 \pm 2{ }^{\circ} \mathrm{C}$ in an orbital shaker $\left(150 \mathrm{rev} \mathrm{min}^{-1}\right)$ for $48 \mathrm{~h}$. The cultures were centrifuged in $50 \mathrm{ml}$ sterile plastic tubes at $6000 \times \mathrm{g}$ for $15 \mathrm{~min}$. The bacterial cells pellets were re-suspended in saline solution $(0.85 \%)$ and adjusted to have a final concentration of $10^{8}$ $\mathrm{CFU} \mathrm{mL}{ }^{-1}$. For making the bacterial mixtures, equal cell densities $\left(10^{8} \mathrm{CFU} \mathrm{mL}^{-1}\right)$ of all individual cultures were mixed together in a $250 \mathrm{~mL}$ sterilized flask (Karličić et al., 2017). The control was inoculated with saline solution $(0.85 \%)$ without bacteria.

Plantlets were subjected to growth evaluation 8 months after the trial started. Plant parameters evaluated were: Biomass (total dry matter, root and shoot dry matter), plant height, root collar diameter (RCD), relative chlorophyll content (RCC), and nitrogen content (Karličić et al., 2017).

\subsection{Data analysis}

For the plantlet growth experiment treatments were arranged using a completely randomized design. Data were analysed using one-way ANOVA, and a Fisher LSD test was performed in the statistical software Statistica, version 5.0 (SAS Institute, Inc.) to compare means of single variables. Differences were considered significant at $P \leq 0.05$. All the experiments were carried out in triplicate and the values shown are mean \pm standard error.

\section{Results}

3.1. Analysis of the chemical properties of the rhizosphere of volcanic soils

The volcanic ash-derived soils in the sampled raulí plots had different chemical characteristics; the most striking differences included the soil organic matter (13.4-27\%) content and aluminum saturation (4.8$37.3 \%$ ) (Table 2). All soil series had moderately acidic to acid $\mathrm{pH}$ values and a low level of available P. The Los Ulmos series had the lowest values of $\mathrm{pH}$, total $\mathrm{N}$ and Olsen P.

3.2. Isolation, screening of plant growth promoting traits, and selection of indole acetic acid producing rhizobacteria

Bacteria were isolated from the rhizosphere of raulí from plantations and native forest; culture-dependent standard plate methods were used. Based on differential colony morphologies and pigmentation, a total of 1,261 bacterial strains were isolated with different culture media. The highest number of isolates was obtained with soil extract agar (515 isolates) and nutrient agar (456 isolates). Growth on Jensen medium produced the lowest amount of isolates (290 isolates).

IAA is a plant phytohormone that stimulates the overproduction of root hairs and lateral roots in plants. A well-developed root system is essential for the successful transplant of tree plantlets. Therefore, the production of IAA was the first criterion for the selection of potential PGPR bacteria (Zavattieri et al., 2016). The production of indole compounds was analyzed for the 1,261 isolated strains and the 100 highest indole compound-producing strains. In the 100 selected strains, IAA production ranged from 10.7 to $81.3 \mu \mathrm{g}$ IAA $\mathrm{mL}^{-1}$. Of these 100 IAA-producing selected strains, 30 strains showed ACCD activity and 36 seemed to have the potential to fix nitrogen (Table 3). In order to further characterize the strains, the 7 isolates that produced the highest amounts of IAA (39 - $49 \mu \mathrm{g}_{\left.\text {IAA } \mathrm{mL}^{-1}\right)}$ were selected for taxonomic identification. 
Table 2. Chemical soil characteristics

\begin{tabular}{lcccccc}
\hline Variable & unit & Pelchuquin & San José & Malihue & Liquiñe & Los Ulmos \\
\hline $\mathrm{pH}\left(\mathrm{H}_{2} \mathrm{O}\right)$ & & $5.3 \pm 0.1 \mathrm{c}$ & $5.7 \pm 0.16 \mathrm{ab}$ & $5.5 \pm 0.3 \mathrm{bc}$ & $5.9 \pm 0.1 \mathrm{a}$ & $5.3 \pm 0.1 \mathrm{c}$ \\
$\mathrm{Nt}$ & $(\%)$ & $0.72 \pm 0.02 \mathrm{a}$ & $0.62 \pm 0.04 \mathrm{~b}$ & $0.77 \pm 0.07 \mathrm{a}$ & $0.49 \pm 0.03 \mathrm{~b}$ & $0.39 \mathrm{c}$ \\
$\mathrm{SOM}$ & $(\%)$ & $24.4 \pm 1 \mathrm{~b}$ & $27 \pm 1.6 \mathrm{a}$ & $21 \pm 2.4 \mathrm{c}$ & $13.4 \pm 1 \mathrm{e}$ & $17.4 \pm 0.8 \mathrm{~d}$ \\
$\mathrm{P}(\mathrm{Olsen})$ & $\left(\mathrm{mg} \mathrm{kg}^{-1}\right)$ & $9 \pm 0.35 \mathrm{a}$ & $5.3 \pm 1.5 \mathrm{ab}$ & $9.7 \pm 8,3 \mathrm{ab}$ & $8.1 \pm 1.1 \mathrm{a}$ & $3.9 \pm 0.42 \mathrm{~b}$ \\
$\mathrm{Al} \mathrm{sat}$ & $(\%)$ & $37.3 \pm 17.1 \mathrm{a}$ & $6 \pm 2.1 \mathrm{~b}$ & $4.8 \pm 4.7 \mathrm{~b}$ & $6.9 \pm 2 \mathrm{~b}$ & $31 \pm 9.4 \mathrm{a}$ \\
\hline
\end{tabular}

Nt: total nitrogen; SOM: soil organic matter; $\mathrm{P}(\mathrm{Olsen})$ : Olsen extracted Phosphorus; $\mathrm{Al}$ sat: Aluminum saturation. ( $\mathrm{n}=3 ; \pm$ standard error).

Table 3. Mechanisms related with plant growth promotion in the 100 highest IAA-producing rhizobacteria strains selected

\begin{tabular}{|c|c|c|}
\hline Mechanisms & $\begin{array}{c}\text { Number of } \\
\text { isolates }\end{array}$ & Observation \\
\hline Auxin production & 100 & $\begin{array}{l}10.7-81.3 \mu \mathrm{g} \mathrm{mL}^{-1} \text {, detection by } \\
\text { HPLC }\end{array}$ \\
\hline $\begin{array}{l}\text { ACC deaminase } \\
\text { (qualitative) }\end{array}$ & 76 & $\begin{array}{l}\text { Bacteria grown in M9 minimal medium } \\
\text { agar using ACC as the sole source of } \\
\text { nitrogen }\end{array}$ \\
\hline $\begin{array}{l}\text { ACC deaminase } \\
\text { (quantitave) }\end{array}$ & 30 & $\begin{array}{l}1.94-5.74 \alpha \text {-Ketobutyrate } \mu \mathrm{g} \mathrm{mL}^{-1} \text {, } \\
\text { detection by HPLC }\end{array}$ \\
\hline Biological nitrogen fixation & 36 & $\begin{array}{l}\text { Detection by PCR using primers } \\
\text { targeting the nifH gene }\end{array}$ \\
\hline
\end{tabular}

\subsection{Genetic identification and phenotypic} characterization of selected IAA-producing rhizobacteria

In order to understand the molecular diversity of the selected IAA-producing rhizobacteria associated with raulí, DNA fingerprinting employing the ERIC-PCR technique was performed. Differences among selected strains were found in the electrophoretic banding patterns. Specifically, strains were divided into four DNA banding patterns: 1 (Noth 6 and Noth 9), 2 (Noth 4, Noth 5, and Noth 10), 3 (Noth 7) and 4 (Noth 8) (Figure 1).

The 7 strains with the greatest ability to produce IAA were identified using 16S rRNA gene sequence analysis. Results showed that all the IAA-producing rhizobacteria strains belonged to the Serratia genus (Gammaproteobacteria; Enterobacteriales; Enterobacteriaceae) (Table 4). Upon analyzing the relationship between the experimental Serratia strains and others characterized as belonging to the genus, it was found that two isolates (Noth 6 and Noth 9) are related to S. myotis and five (Noth 4, Noth 5, Noth 7, Noth 8 and Noth 10) are related to $S$. liquefaciens group (Figure 2, Table 4). Phenotypic characterization of the 7 selected strains is shown in Table 5. Similarly to the results obtained from the ERIC-PCR analysis (Figure 1), the Noth 4, Noth 5, Noth 7, and Noth 10 strains did not differ phenotypically. In addition, the strains Noth 6 and Noth 9 were phenotypically similar. Conversely, the strain Noth 8 differed from Noth 4, Noth 5, Noth 7 and Noth 10 in its ability to produce the enzyme oxidase and in the ability to produce acid from sorbitol. Noth 8 differed from Noth 6, Noth 7, and Noth 9 due to its utilization of citrate as a sole carbon source and due to the production of the enzyme ACC deaminase (Table 5). 


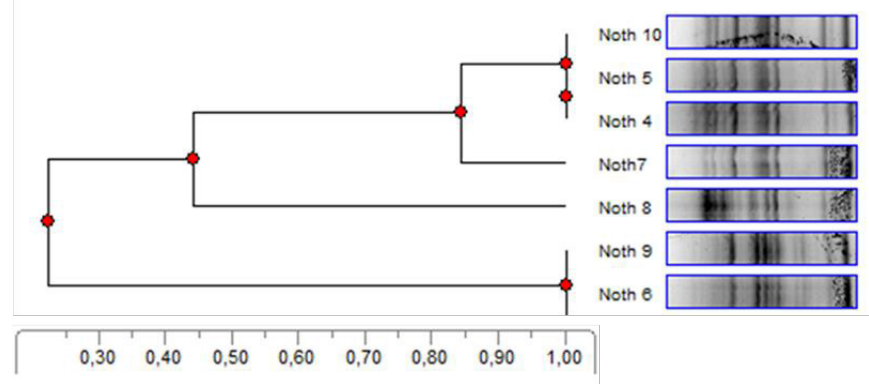

Figure 1. Enterobacterial Repetitive Intergenic Consensus (ERIC)-PCR fingerprinting of selected rhizobacteria isolates

Table 4. Identification of selected IAA-producing rhizobacteria strains

\begin{tabular}{|c|c|c|c|c|}
\hline Strain & $\begin{array}{c}\text { Soil series and } \\
\text { medium isolation }^{\mathrm{a}}\end{array}$ & 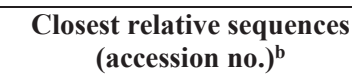 & $\begin{array}{c}\text { Similarity } \\
(\%)^{b}\end{array}$ & $\begin{array}{l}\text { Accession } \\
\text { no. }\end{array}$ \\
\hline Noth 4 & $\begin{array}{l}\text { Los Ulmos } \\
\text { SEA }\end{array}$ & $\begin{array}{l}\text { Serratia liquefaciens } \\
\text { (CP006252) }\end{array}$ & 99.25 & MF716551 \\
\hline Noth 5 & $\begin{array}{l}\text { Malihue } \\
\text { NA }\end{array}$ & $\begin{array}{l}\text { Serratia liquefaciens } \\
\text { (CP006252) }\end{array}$ & 99.25 & MF716552 \\
\hline Noth 6 & $\begin{array}{l}\text { Malihue } \\
\text { NA }\end{array}$ & Serratia myotis (KJ739884) & 99.86 & MF716553 \\
\hline Noth 7 & $\begin{array}{l}\text { Malihue } \\
\text { NA }\end{array}$ & $\begin{array}{l}\text { Serratia liquefaciens } \\
\text { (CP006252) }\end{array}$ & 99.23 & MF716554 \\
\hline Noth 8 & $\begin{array}{l}\text { Malihue } \\
\text { SEA }\end{array}$ & $\begin{array}{l}\text { Serratia liquefaciens } \\
\text { (CP006252) }\end{array}$ & 99.26 & MF716555 \\
\hline Noth 9 & $\begin{array}{l}\text { San José } \\
\text { SEA }\end{array}$ & Serratia myotis (KJ739884) & 99.79 & MF716556 \\
\hline Noth 10 & $\begin{array}{l}\text { San José } \\
\text { SEA }\end{array}$ & $\begin{array}{l}\text { Serratia liquefaciens } \\
\text { (CP006252) }\end{array}$ & 99.24 & MF716557 \\
\hline
\end{tabular}

aJMA: Jensen's Medium Agar, SEA: Soil Extract Agar, NA: Nutritive Agar

${ }^{b}$ The phylogenetic assignment is based on sequence blast against the GenBank database from NCBI (http:// http://www.ezbiocloud.net/eztaxon/identify).

${ }^{\mathrm{c}}$ GenBank accession numbers. 


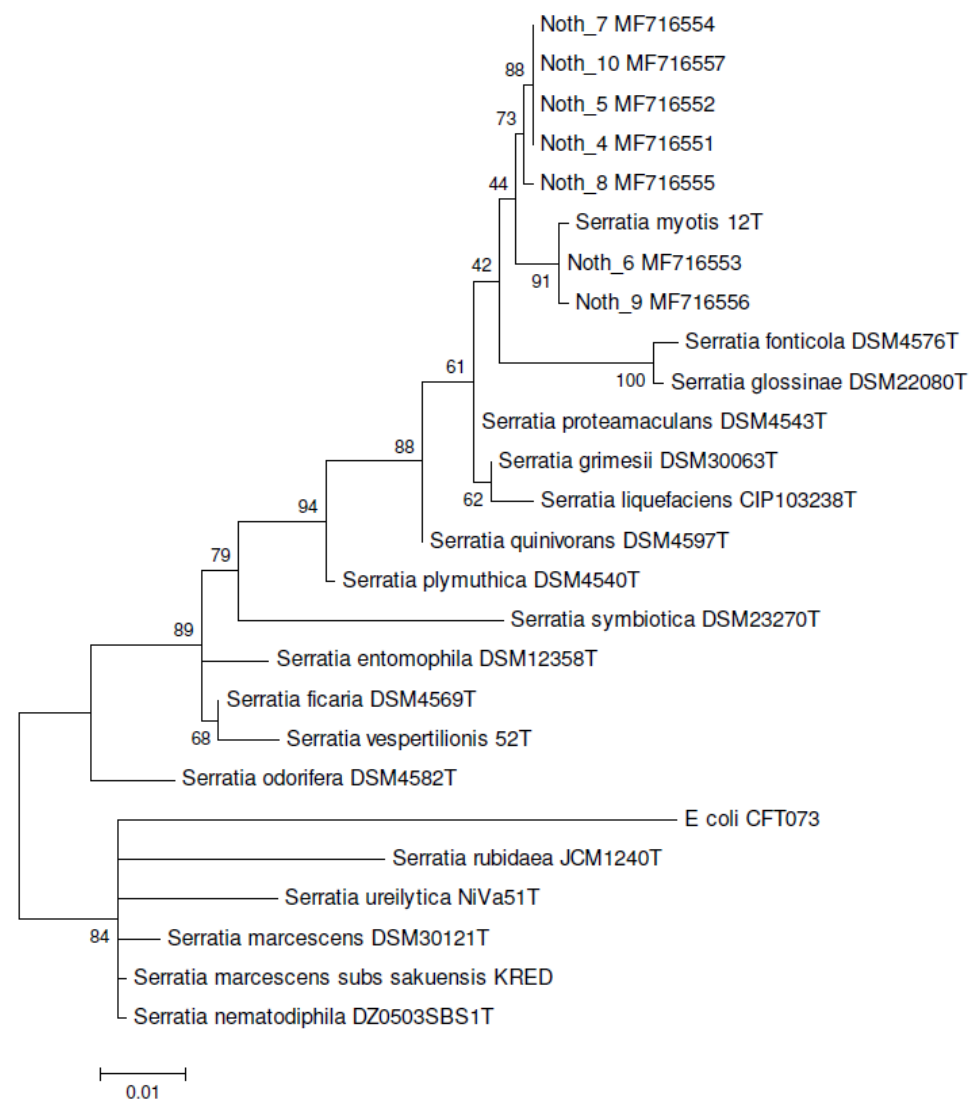

Figure 2. Phylogenetic relationship of bacterial strains among Serratia species based on nearly full-length $16 \mathrm{~S}$ rRNA gene sequences. Numbers above branches indicate pseudoreplicate bootstrap values obtained by Maximum Likelihood-Kimura 2 analysis and 1,000 bootstraps 
Table 5. Phenotypic characterization of seven selected IAA-producing rhizobacteria isolates from N. alpina rhizosphere. + Positive, - negative test

\begin{tabular}{|c|c|c|c|c|c|c|c|}
\hline Feature & $\begin{array}{c}\text { Noth } \\
4\end{array}$ & $\begin{array}{c}\text { Noth } \\
5\end{array}$ & $\begin{array}{c}\text { Noth } \\
6\end{array}$ & $\begin{array}{c}\text { Noth } \\
7\end{array}$ & $\begin{array}{c}\text { Noth } \\
8\end{array}$ & $\begin{array}{c}\text { Noth } \\
9\end{array}$ & $\begin{array}{c}\text { Noth } \\
10\end{array}$ \\
\hline $\begin{array}{l}\text { Morphology in staining of } \\
\text { Gram }^{\mathrm{a}}\end{array}$ & GNR & GNR & GNR & GNR & GNR & GNR & GNR \\
\hline Growth $22^{\circ} \mathrm{C}$ & + & + & + & + & + & + & + \\
\hline Growth $37^{\circ} \mathrm{C}$ & + & + & + & + & + & + & + \\
\hline Growth $42^{\circ} \mathrm{C}$ & + & + & + & + & + & + & + \\
\hline Growth in SS agar & + & + & + & + & + & + & + \\
\hline $\begin{array}{l}\text { Growth in MacConkey } \\
\text { agar }\end{array}$ & + & + & + & + & + & + & + \\
\hline Motility & - & - & - & - & - & - & - \\
\hline Acid from lactose & - & - & - & - & - & - & - \\
\hline Acid from glucose & + & + & + & + & + & + & + \\
\hline Acid from sorbitol & + & + & - & + & - & - & + \\
\hline Acid from arabinose & + & + & + & + & + & + & + \\
\hline Catalase & + & + & + & + & + & + & + \\
\hline Oxidase & - & - & + & - & + & + & - \\
\hline Utilization of Citrate & + & + & - & + & + & - & + \\
\hline Urease & - & - & - & - & - & - & - \\
\hline Voges Proskauer & + & + & + & + & + & + & + \\
\hline Methyl Red & - & - & - & - & - & - & - \\
\hline DNAsa & + & + & + & + & + & + & + \\
\hline Lysine & + & + & + & + & + & + & + \\
\hline Ornithine & + & + & + & + & + & + & + \\
\hline Hemolysis & $\beta$ & $\beta$ & $\beta^{\mathrm{b}}$ & $\beta$ & $\beta$ & $\beta^{\mathrm{b}}$ & $\beta^{\mathrm{b}}$ \\
\hline $\begin{array}{l}\text { Plant growth promoting } \\
\text { traits }\end{array}$ & & & & & & & \\
\hline Indol acetic acid ${ }^{c}$ & + & + & + & + & + & + & + \\
\hline Growth in $\mathrm{N}$-free medium & + & + & + & + & + & + & + \\
\hline ACC deaminase activity & - & - & + & - & - & + & - \\
\hline
\end{tabular}

${ }^{\mathrm{a}} \mathrm{GNR}$ : Gram-negative rod.

${ }^{\mathrm{b}}$ Developement of $\beta$ hemolysis after $48 \mathrm{~h}$.

'Test for Indol acetic acid production in peptone broth with 1\% tryptophan via Salkowski's method.

3.4. Nursery inoculation experiment with IAAproducing rhizobacteria

In order to study the effects of the Serratia strains isolates on plant growth, a nursery experiment was performed. The raulí plantlets were inoculated with $3 \mathrm{bac}-$ terial strain mixtures; thus, mix 1 (Noth 4, Noth 5 and Noth 6) contained strains with IAA, ACCD and BNF traits; mix 2 (Noth 7 and Noth 8) contained strains with IAA and BNF traits; and mix 3 (Noth 9 and Noth 10) contained strains with IAA, ACCD and BNF traits. Compared to the control that produced no effect on growth, all of the mixtures significantly stimulated at least some of the plant growth parameters. The growth parameters that were significantly $(P \leq 0.05)$ increased after bacterial inoculation compared to the control were: Root collar diameter (52-60\%), height (46$49 \%$ ), relative chlorophyll content (20-28\%) and nitrogen content (51-68\%) (Table 6). Out of the 3 mixtures tested, the highest stimulation of plant biomass was observed with mix 1 . It should be noted that only mix 1 produced significantly greater $(P \leq 0.05)$ plantlet total biomass (206\%), root dry matter (231\%) and shoot dry biomass (191\%), compared to the control (Table 6). 
Table 6. Effect of bio-inoculation with native Serratia mixtures on Raulí (Nothofagus alpina) plantlet parameters grown in a nursery

\begin{tabular}{lcccc}
\hline \multicolumn{1}{c}{ Plant parameters } & Control & Mix 1 & Mix 2 & Mix 3 \\
\hline RCD $(\mathrm{mm})$ & $2.1 \pm 0.11 \mathrm{~b}$ & $3.4 \pm 0.26 \mathrm{a}$ & $3.5 \pm .34 \mathrm{a}$ & $3.2 \pm 0.05 \mathrm{a}$ \\
Height $(\mathrm{cm})$ & $10 \pm 1 \mathrm{~b}$ & $14.9 \pm 1.1 \mathrm{a}$ & $14.6 \pm 1.1 \mathrm{a}$ & $14.9 \pm 1.2 \mathrm{a}$ \\
RCC $(\mathrm{SPAD})$ & $23.1 \pm 1 \mathrm{~b}$ & $27.8 \pm 0.7 \mathrm{a}$ & $29.6 \pm 0.7 \mathrm{a}$ & $28.5 \pm 1.6 \mathrm{a}$ \\
Root dry matter $(\mathrm{g})$ & $0.29 \pm 0.08 \mathrm{~b}$ & $0.96 \pm 0.22 \mathrm{a}$ & $0.6 \pm 0.08 \mathrm{ab}$ & $0.68 \pm 0.13 \mathrm{ab}$ \\
Shoot dry matter $(\mathrm{g})$ & $0.49 \pm 0.06 \mathrm{~b}$ & $1.43 \pm 0.33 \mathrm{a}$ & $1.01 \pm 0.14 \mathrm{ab}$ & $1.06 \pm 0.18 \mathrm{ab}$ \\
Dry matter $(\mathrm{g})$ & $0.78 \pm 0.14 \mathrm{~b}$ & $2.39 \pm 0.55 \mathrm{a}$ & $1.61 \pm 0.22 \mathrm{ab}$ & $1.75 \pm 0.32 \mathrm{ab}$ \\
N content $(\%)$ & $0.47 \pm 0.089 \mathrm{~b}$ & $0.79 \pm 0.012 \mathrm{a}$ & $0.76 \pm 0.031 \mathrm{a}$ & $0.71 \pm 0.006 \mathrm{a}$ \\
\hline
\end{tabular}

RCD: Root collar diameter; RCC: Relative chlorophyll content. ( $\mathrm{n}=3 ; \pm$ standard error).

\section{Discussion}

In the present study, native bacteria were isolated from the rhizosphere of rauli growing in different volcanic soils, and these bacteria were screened for the presence of putative plant growth-promoting traits. The isolation and identification of native bacteria is an important first step in identifying candidate bacteria with potential PGPR traits adapted to different soil environments. In southern Chile, raulí grow on ash-derived volcanic soils known as andisols, which are characterized by a high level of metal phytotoxic cations $\left(\mathrm{Al}^{+3}\right.$ and $\left.\mathrm{Mn}^{+2}\right)$ in the soil solution (Valle and Carrasco, 2017). These chemical properties of the rhizosphere soil have a relevant influence in the occurrence and performance of culturable rhizobacteria that contain beneficial traits for plant growth (Martínez et al., 2011).

In this study, 1,261 bacteria were isolated from the rhizosphere of raulí growing in plantations and in one native forest in southern Chile. These isolates were screened for well-known traits commonly attributed to PGPR such as IAA production, ACCD activity and BNF. Currently it is well known that IAA production is widespread among soil bacteria that inhabit the rhizosphere of plants, and IAA production promotes growth and development (Egamberdieva et al., 2017; Viscardi et al., 2016); thus, this trait was our principal criterion for selection. Others have also noted that IAA production can be used for the selection of effective plant growth promoting rhizobacteria (Etesami et al., 2015; Mestre et al., 2017). The main IAA-producing bacteria belonging to the Aeromonas, Azotobacter, Bacillus, Burkholderia, Enterobacter, Pseudomonas, Rhizobium and Serratia genera have been isolated from different rhizospheric soils (Egamberdieva et al., 2017; Koo and Cho, 2009; MartinezViveros et al., 2010). The ability of rhizobacteria to produce phytohormones has long been believed to be a major factor affecting plant root growth; specifically, it is thought that these phytohormones allow the plant to extract nutrients from a greater volume of soil (Egamberdieva et al., 2017). Additionally, other studies have shown that IAA produced by PGPR affects tree root morphology (George et al., 2013) and metabolic processes such as photosynthesis, biosynthesis of various metabolites, and resistance to stressful conditions modulated by auxins (Egamberdieva et al., 2017; Karličić et al., 2017). Accordingly, IAA indirectly increases water and nutrient supplies leading to higher root exudation and biomass production in forest species (Egamberdieva et al., 2017; Karličić et al., 2017). Furthermore, it has been shown that IAA triggers the activation of the central energy metabolism of Escherichia coli cells (Bianco et al., 2006b) and is also able to enhance protection against various 
abiotic stresses such as UV and low pH (Bianco et al., 2006a). From this, we hypothesize that the high levels of IAA production by the rhizobacteria studied here might be related to the defense against stress caused by the low $\mathrm{pH}$ and high aluminum concentration in these soils. Overall, our results are in agreement with previous reports that indicate that the production of IAA is a widely distributed trait in culturable bacteria isolated from plants grown in Chilean andisols (Jorquera et al., 2014; Martínez et al., 2011).

Here we found that several of our isolates had the ability to produce IAA, had ACCD activity, and had the potential to fix nitrogen. It is well known that plantassociated bacteria can have multiple plant growthpromoting traits (Martinez-Viveros et al., 2010). It has been reported by Etesami et al. (2015) that bacterial isolates with positive IAA and ACC deaminaseproducing traits can increase plant colonization. Bacterial IAA together with ACC deaminase increase root surface area and length and thereby provide the plant with access to soil nutrients. Increased nutrient availability is important during situations of plant stress such as during transplantation. Additionally, BNF is an important plant growth promoting trait, and many non-symbiotic $\mathrm{N}$-fixing rhizospheric bacteria belonging to the genera Azoarcus, Azospirillum, Burkholderia, Gluconacetobacter, Pseudomonas and Serratia have been isolated from different soils (Dastager et al., 2011; Martinez-Viveros et al., 2010). Overall, the PGP traits evaluated here could be targeted to aid the successful transplantation of rauli trees in volcanic soils. Specifically, rhizobacteria with these traits could be used to support the growth and development of trees despite the low $\mathrm{pH}$ and the high concentration of metals $\left(\mathrm{Al}^{3+}\right.$ and $\left.\mathrm{Mn}^{2+}\right)$ in the soil solution (Karličić et al., 2016; Kavino et al., 2010).

In the present study, the highest IAA-producing bacteria isolated from the rhizosphere of raulí grown in different volcanic ash-derived soil belonged to the genus
Serratia. ERIC-PCR fingerprinting analysis showed that the Serratia isolates grouped into four genotypes. Analysis of the 16S rRNA gene showed that the isolates Noth 6 and Noth 9 can be identified as S. myotis and strains Noth 4, Noth 5, Noth 7, Noth 8 and Noth 10 are related the $S$. liquefaciens group. The $S$. liquefaciens group includes three different species $-S$. liquefaciens, S. grimesii, S. proteamaculans- that are not distinguishable by $16 \mathrm{~S}$ rRNA sequencing. Therefore, further analysis would be necessary to identify the strains to the species level. On the other hand, phenotypic characterization indicated that all 7 isolates were able to grow in $\mathrm{N}$-free medium, which shows their potential capacity to fix nitrogen. Additionally, Noth 6 and Noth 9 isolates showed ACCD activity. Several reports have shown that Serratia species have PGPR potential (Dastager et al., 2011; George et al., 2013). Furthermore, previous studies have identified PGPR strains from rhizosphere of Chilean volcanic soils as belonging to the Serratia genus (Jorquera et al., 2014; Martínez et al., 2011). Thus, this group of bacteria have the potential to enhance plant development in this kind of soil.

The evaluation of the plant growth-promoting effects by the rhizobacteria was carried out in a nursery. For the inoculation assay, we selected seven Serratia isolates with PGPR traits favoring IAA production, ACC deaminase activity, and BNF. The nursery experiment results showed that when the Serratia strains were added to raulí plantlets an increased RCD (56\%), height (47.5\%), RCC (24\%) and N content $(59.5 \%)$ was found. On the other hand, only plants with mix 1 added had increased root dry matter (2.3 fold), shoot dry matter (1.9 fold) and total dry matter ( 2 fold). Aligned with these results, George et al. (2013) have shown that inoculation with $S$. marcescens increases biomass (total dry weight) in coconut seedlings (19\%), cowpea seedlings (104\%) and paddy seedlings $(60 \%)$ compared to non-inoculated controls. 
In addition, George et al. (2013) report a significant increase in the collar girth (6.2\%) and $\mathrm{N}$ uptake (54 $\%$ ) of coconut seedlings. Plantlet root collar diameter (RCD) is an indicator of plantlet quality, and larger RCDs are usually correlated with higher survival and growth (South et al., 1985). Furthermore, increased RCDs can be related to increases in root biomass. The present study demonstrates that Serratia strain inoculation increases plantlet N-content, and this can be attributed to the $\mathrm{N}$ fixation ability of these strains. Regardless, direct transfer of $\mathrm{N}$ should be measured to verify these results (Bergottini et al., 2015). To our knowledge, this is the first report where rhizosphere raulí-associated Serratia strains have been shown to promote growth of raulí plantlets in nursery conditions. Overall, the potential of these rhizobacteria to be implemented as a biofertilizer in nursery management requires further investigation.

\section{Conclusions}

The present work reveals that raulí grown in volcanic soils contain rhizobacterial populations that harbour traits that promote plant growth. Specifically, these traits include the production of indole acetic acid, 1-aminocyclopropane-1-carboxilate deaminase activity and biological $\mathrm{N}$ fixation. The most efficient culturable indole acetic acid-producing rhizobacteria were selected and identified as Serratia species. Moreover, this study shows that indigenous Serratia strains can enhance raulí plantlet quality in nursery conditions. Thus, these rhizobacteria are promising inoculants for the development of plantlets to transplant into volcanic soils.

\section{Acknowledgements}

FONDECYT Initiation into research no. 11130352 , CONICYT-Chile, for providing the financial support.
OAM is thankful to Erica Pérez and Angélica Tocol for her valuable technical help during the soil sampling and the nursery experiments. We thank Emily C. Giles for helpful comments and English corrections on the manuscript.

\section{References}

Angulo, V.C., Sanfuentes, E.A., Rodríguez, F., Sossa, K.E. 2014. Caracterización de rizobacterias promotoras de crecimiento en plántulas de Eucalyptus nitens. Rev. Argent. Microbiol. 46:338-347.

Beltran, H.A., Chauchard, L., Iaconis, A., Martinez P., G. 2017. Volume and taper equations for commercial stems of Nothofagus obliqua and $N$. alpina. CERNE 23: 299-309.

Bergottini, V.M., Otegui, M.B., Sosa, D.A., Zapata, P.D., Mulot, M., Rebord, M., Zopfi, J., Wiss, F., Benrey, B., Junier, P. 2015. Bio-inoculation of yerba mate seedlings (Ilex paraguariensis St.Hill.) with native plant growth-promoting rhizobacteria: a sustainable alternative to improve crop yield. Biol. Fertil. Soils 51: 749-755.

Bianco, C., Imperlini, E., Calogero, R., Senatore, B., Amoresano, A., Carpentieri, A., Pucci, P., Defez, R. 2006a. Indole-3-acetic acid improves Escherichia coli's defences to stress. Arch. Microbiol. 185: 373-382.

Bianco, C., Imperlini, E., Calogero, R., Senatore, B., Pucci, P., Defez, R. 2006b. Indole-3-acetic acid regulates the central metabolic pathways in Escherichia coli. Mol. Microbiol. 152: 2421-2431.

Chanway, C.P. 1997. Inoculation of tree roots with plant growth promoting rhizobacteria: An emerging technology for reforestation. For. Sci. 43: 99-112.

Coenye, T., Schouls, L.M., Govan, J.R.W., Kersters, K., Vandamme, P. 1999. Identification of Burkholderia species and genomovars from cystic 
fibrosis patients by AFLP fingerprinting. Int. J. Syst. Evol. Microbiol. 49: 1657-1666.

Dastager, S.G., Deepa C.K., Pandey, A. 2011. Potential plant growth-promoting activity of Serratia nematodiphila NII-0928 on black pepper (Piper nigrum L.). World J. Microbiol. Biotechnol. 27: 259-265.

Donoso, P., Donoso, C., Marchelli, P., Gallo, L., Escobar, B. 2006. Nothofagus nervosa (Phil.) Dim. Et Mil. In: Donoso, C. (ed.) Las especies arbóreas de los bosques templados de Chile y Argentina. Autoecologia. Marisa Cuneo Ediciones, Valdivia, Chile. 448-461.

Egamberdieva, D., Wirth, S.J., Alqarawi, A.A., Abd Allah, E.F., Hashem, A. 2017. Phytohormones and beneficial microbes: essential components for plants to balance stress and fitness. Front. Microbiol. https://doi.org/10.3389/fmicb.2017.02104.

Etesami, H., Alikhani, H.A., Mirseyed Hosseini, H. 2015. Indole-3-acetic acid and 1-aminocyclopropane-1-carboxylate deaminase: bacterial traits required in rhizosphere, rhizoplane and/or endophytic competence by beneficial bacteria. In: Maheshwari, D.K. (ed.), Bacterial Metabolites in Sustainable Agroecosystem, Sustainable Development and Biodiversity 12, DOI 10.1007/978-3319-24654-3_8. Pp. 183-258.

George, P., Gupta, A., M Gopal, L Thomas, GV. Thomas. 2013. Multifarious beneficial traits and plant growth promoting potential of Serratia marcescens KiSII and Enterobacter sp. RNF267 isolated from the rhizosphere of coconut palms (Cocos nucifera L.). World J. Microbiol. Biotechnol. 29: 109-117.

Grimont, F., Grimont, P.A.D. 2006. The Genus Serratia. In: M Dworkin, S Falkow, E Rosenberg, K-H Schleifer, E Stackebrandt (Eds) The Prokaryotes Volume 6: Proteobacteria: Gamma Subclass, pp. 219-244. DOI: 10.1007/0-387-30746-x_11.
Houf, K., De Zutter, L., Jan Van Hoof, Vandamme, P. 2002. Assessment of the genetic diversity among Arcobacters isolated from poultry products by using two PCR-based typing methods. Appl. Environ. Microbiol. 68: 2172-2178.

Jorquera, M.A., Inostroza, N.G., Lagos, L.M., Barra, P.J., Marileo, L.G., Rilling, J.I., Campos, D.C., Crowley, D.E., Richardson, A.E., Mora, M.L. 2014. Bacterial community structure and detection of putative plant growth-promoting rhizobacteria associated with plants grown in Chilean agro-ecosystems and undisturbed ecosystems. Biol. Fertil. Soils 50: 1141-1153.

Karličić, V., Curguz,V.G., Raičević, V. 2016. The alleviation of reforestation challenges by beneficial soil microorganisms. Reforesta 1: 238-260.

Karličić, V., Radić, D., Jovičić-Petrović, J., Lalević, B., Morina, F., Golubović Curguz, V., Raičević, V. 2017. Use of overburden waste for London plane (Platanus $\times$ acerifolia) growth: the role of plant growth promoting microbial consortia. iForest 10: 692-699.

Kavino, M., Harish, S., Saravanakumar, D., Jeyakumar, P., Kumar, N., Samiyappan, R. 2010. Biological hardening-a new approach to enhance resistance against biotic and abiotic stresses in micropropagated plants. Tree For. Sci. Biotech. 4; 11-21.

Koo, S.Y., Cho, K.S. 2009.Isolation and characterization of a plant growth-promoting rhizobacterium, Serratia sp. SY5. J. Microbiol. Biotechnol. 19: 1431-1438.

Lucy M., Reed, E., Glick, B.R. 2004. Applications of free living plant growth-promoting rhizobacteria. A. Van Leeuw. J. Microb. 86: 1-25.

MacFaddin, J.F. 2000. Biochemical Test for Identification of Medical Bacteria 3th edition, Lippincott Williams \& Wilkins, Inc. United States of America. 
Martínez, O.A., Jorquera, M.A., Crowley, D.E., Mora, M.L. 2011. Influence of nitrogen fertilisation on pasture culturable rhizobacteria occurrence and the role of environmental factors on their potential PGPR activities. Biol. Fertil. Soils 47: 875-885.

Martinez-Viveros, O., Jorquera, M.A., Crowley, D.E., Gajardo, G., Mora, M.L. 2010. Mechanisms and practical considerations involved in plant growth promotion by rhizobacteria. J. Soil Sci. Plant Nutr. 10: 293-319.

Mestre M.C., M.J. Pastorino, A.G. Aparicio, S.B. Fontenla. 2017. Natives helping foreigners? The effect of inoculation of poplar with patagonian beneficial microorganisms. J. Soil Sci. Plant Nutr. 17: 1028-1039.

Patten, C.L., Glick, B.R. 2002. Role of Pseudomonas putida indoleacetic acid in development of the host plant root system. Appl, Environ. Microbiol. 68: 3795-3801.

Penrose, D.M., Glick, B.R. 2003. Methods for isolating and characterizing ACC deaminase-containing plant growth-promoting rhizobacteria. Physiol, Plant. 118: 10-15.

Petersen, L.M., Tisa, L.S. 2013. Friend or foe? A review of the mechanisms that drive Serratia towards diverse lifestyles. Can. J. Microbiol. 59: 627-640.

Sadzawka, A., Carrasco, M., Grez, R., Mora, M.L., Flores, H., Neaman, A. 2006. Métodos de análisis recomendados para los suelos de Chile. Instituto de Investigación Agropecuaria. Serie Actas INIA No34. INIA. Santiago, Chile, 164p.
Singh, R.P., Jha, P.N. 2016. The multifarious PGPR Serratia marcescens CDP-13 augments induced systemic resistance and enhanced salinity tolerance of wheat (Triticum aestivum L.). PLoS ONE 11: e0155026.

South, D.B., Boyer, J.N., Bosch, L. 1985. Survival and growth of Loblolly Pine as influenced by seedling grade: 13-year results. South J. Appl. For. 9: 76-81.

Valle S.R., Carrasco J. 2018. Soil quality indicator selection in Chilean volcanic soils formed under temperate and humid conditions. Catena 162: 386-395.

Viscardi, S., Ventorino, V., Duran, P., Maggio, A., De Pascale, S., Mora, M.L., Pepe, O. 2016. Assessment of plant growth promoting activities and abiotic stress tolerance of Azotobacter chroococcum strains for a potential use in sustainable agriculture. J. Soil Sci. Plant Nutr. 16: 848-863

Wartiainen, I., Eriksson, T., Zheng, W., Rasmussen, U. 2008. Variation in the active diazotrophic community in rice paddy-nifH PCR-DGGE analysis of rhizosphere and bulk soil. Appl. Soil Ecol. 39: $65-75$.

Zavattieri, M.A., Ragonezi, C., Klimaszewska, K. 2016. Adventitious rooting of conifers: influence of biological factors. Trees 30: 1021-1032. 